\title{
Prescriptive Water Rights in California: An Addendum
}

\author{
Delger Trowbridge*
}

THE ARTICLE of Mr. Russell R. Kletzing, Prescriptive Water Rights in 1 California: Is Application a Prerequisite?, appearing in the September, 1951, issue of this Review, ${ }^{1}$ is a sound and excellent paper and the conclusions stated seem to be unassailable. A consideration of recent cases in other western. states, including Utah before and since its interesting 1939 legislation, ${ }^{2}$ emphasizes the soundness of $\mathrm{Mr}$. Kletzing's conclusions.

The issue discussed in most of the western appellate courts is whether the so-called "water codes," now adopted in some form in every western state, provide an exclusive or only an alternative method for acquiring new water rights by physical diversions of water.

On United States lands new water rights are acquired only by appropriation, since according to well-known principles prescriptive rights can never be acquired against the government. ${ }^{3}$ However, where watercourses traverse private lands, rights may be acquired by prescription in most of the western states. ${ }^{4}$ The codes usually provide for filing formal applications, accompanied by maps and engineering data, with some state officer who then holds hearings and grants permits, often on conditions protecting the rights of other water users, present or future. The officer, of course, has the power to deny permits for good cause shown.

The majority of the western courts have held that these codes are in the nature of recording acts, giving priority to applicants as of their filing dates regardless of the length of time of use, and are not the exclusive method for acquiring new rights. The "continued, open, notorious, exclusive, uninterrupted, and adverse use and enjoyment of the water under a claim of right" for the statutory period (in California five years) ${ }^{5}$ in most western jurisdictions constitutes the perfection of new water rights as of the end of the statutory period. These rights often are not matters of public record and when in question require proof of all the necessary facts to the satisfaction of a court.

In Wyoming (and in Utah by statute since $1939^{\mathrm{T}}$ ) the courts hold that

* Member, California Bar.

139 CALIF. L. Rev. 369 (1951).

2 Utali Laws 1939, c. 111; 100 Utali Laws Ann, c. 3, \{1 (1943).

3 Smith v. Hawkins, 110 Cal. 122, 42 Pac. 453 (1895).

4 Contra: Wyoming, Utah by statute and possibly Oregon and New Mexico. See text at notes 6-9 infra.

5 San Diego v. Cuyamaca Water Co., 209 Cal. 105, 287 Pac. 475 (1930); Big Rock M.W. Co. v. Valyermo Ranch Co., 78 Cal. App. 266, 273, 248 Pac. 264, 267 (1926); Bloss v. Rahilly, 16 Cal. 2d 70, 78, 104 P. 2d 1049, 1053 (1940).

8 Wyoming Ranch v. Hammond Packing Co., 33 Wyo. 14, 236 Pac. 764 (1925); Whalon v. Canal Co., 11 Wyo. 313, 71 Pac. 995 (1903) semble.

7 Utah Laws 1939, c. 111. 
all the formalities of the water codes must be complied with and that no new rights by appropriation or prescription can be acquired without compliance. In Oregon ${ }^{8}$ and $\mathrm{New} \mathrm{Mexico}^{9}$ the courts are not clear but seem to lean the same way.

Mr. Kletzing quotes Mr. Samuel C. Wiel's excellent article ${ }^{10}$ with great enthusiasm, but unfortunately $\mathrm{Mr}$. Wiel's article was written just a little too early as far as most of the decisive cases are concerned. The principal Utah case referred to by Mr. Wiel, Deseret Company v. Hoopiana, ${ }^{11}$ as ruling out prescriptive water rights, was shortly thereafter overruled by Wrathall $v$. Johnson, ${ }^{12}$ which expressly recognized the validity of water rights acquired by adverse possession in Utah. There are also other cases since Deseret Company v. Hoopiana which have recognized the validity of prescriptive water rights in Utah. The decision in Wrathall v. Johnson led the Utah Legislature in 1939 to add the following interesting sentence to its water code: ${ }^{13}$

No right to the use of water either appropriated or unappropriated can be acquired by adverse use or adverse possession.

This statute came before the Utah Supreme Court for consideration in 1943 in the case of Wellsville Company v. Lindsay Company, ${ }^{14}$ and in applying it the court clearly held that prescriptive rights to water acquired prior to passage of this statute in 1939 were valid. Mr. Justice Hoyt, in his dissenting opinion, ${ }^{15}$ conceded that the 1939 act was not retroactive. He therefore desired to limit some of the language in the majority opinion defining prescriptive rights prior to 1939 , since he realized that if these rights existed they would not be affected by the legislation. While he did not say so, it seems clear that neither the court nor the legislature could, under principles of constitutional law, seriously diminish established water rights (which the court held pre-1939 prescriptive rights to be) except by condemnation proceedings. ${ }^{16}$ This is also made clear in the admirable article of Edward F. Treadwell entitled Developing a New Philosophy of Water Rights. ${ }^{17}$

On the basis of the court decisions to date, only Wyoming, ${ }^{18}$ of all the western states, has squarely held that the statutory method for appropriat-

8 Tudor v. Jaca, 178 Ore. 126, 164 P.2d 680 (1945); Oliver v. Skinner and Lodge, 190 Ore. 423, 226 P.2d 507 (1951); Staub v. Jensen, 180 Ore. 682, 178 P.2d 931 (1947).

${ }^{9}$ Farmers Dev. Co. v. Rayado L. \& I. Co., 28 N. M. 357, 213 P.2d 2 (1923) semble; the court seems to be in doubt in Pioneer Irrigating Ditch Co. v. Blashek, 41 N.M. 99, 64 P.2d 388 (1937). (1926).

10 Wiel, Unregistered Water Appropriations at Law and in Equity, 14 Carr. L. REv. 427

1166 Utah 25, 239 Pac. 479 (1925).

1286 Utah 50, 40 P.2d 755 (1935).

13 Utah Laws 1939, c. 111.

14104 Utah 448, 137 P.2d 634 (1943).

$15 I d$. at 485,137 P.2d at 655 .

16 United States v. Gerlach Livestock Co., 339 U.S. 725 (1950); Hillside Water Co. v. Los Angeles, $10 \mathrm{Cal} .2 \mathrm{~d} 67 \%, 76$ P.2d 681 (1938).

1738 CaxIF. L. Rev. 572, 579-580 (1950).

18 Supra note 6. 
ing water is exclusive and that prescriptive rights cannot be acquired by mere adverse possession, as in the case of land.

The states upholding by decision the acquisition of water rights by adverse possession alone are: Colorado, ${ }^{19}$ Idaho, ${ }^{20}$ Montana, ${ }^{21}$ Nevada, ${ }^{22}$ $\mathrm{Utah}^{23}$ (reversed by statute) and Washington. ${ }^{24}$

There is nothing to add regarding the position of the California courts because of the paucity of decisions as to the effect of its water code, as pointed out by Mr. Kletzing.

The decisions referred to above make it clear that rights to water already acquired by five years' adverse possession in California, should be held definite, valid rights which neither the suprenie court nor the legislature can at this time affect.

10 De Haas v. Benesch, 116 Colo. 344, 181 P.2d 453 (1947); Archuleta v. Ditch Co., 118 Colo. 43, 192 P.2d 891 (1948).

20 Basinger v. Taylor, 36 Idaho 591, 211 Pac. 1085 (1922); Crane Falls Co. v. Snake River Co., 24 Idaho 63, 77, 133 Pac. 655, 661 (1913) ; Hinton v. Little, 50 Idaho 371, 296 Pac. 582 (1931).

21 Clausen v. Armington, 123 Mont. 1, 212 P.2d 440 (1949); Murray v. Tingley, 20 Mont. 260, 50 Pac. 723 (1897).

22 Application of Filipini, 202 P.2d 535, 539 (Nev. 1949).

23 Wrathall v. Johnson, supra note 12; Hammond v. Johnson, 94 Utah 20, 66 P.2d 894 (1937) ; Sinith v. Sanders, 112 Utah 517, 189 P.2d 701 (1948).

24 In re Crab Creek and Moses Lake, 134 Wash. 7, 235 Pac. 37 (1925) ; Lawrence v. Southard, 192 Wash. 287, 73 P.2d 722 (1937). 